\title{
EDUVELOP
}

Journal of English Education and Development

Volume 1, No. 1, September 2017

ISSN 2597-713X (print)

ISSN 2597-7148 (online)

\section{THE EFFECT OF THE USE OF STORIES IN IMPROVING THE WRITING ABILITY OF THE SECOND YEAR STUDENTS OF MADRASAH TSANAWIYAH NEGERI MANGEMPANG BARRU}

\author{
Syamsiah \\ MTs Mangempang Barru \\ Address: JL. A.A BAU MASSEPE NO.106, -, Kec. Barru, Kab. Barru, Sulawesi Selatan \\ Phone: 0821877148507 \\ Email: ciasyam14@gmail.com
}

\begin{abstract}
This research investigated the implementation of the use of stories in improving the students' writing ability. The objectives of this research were (1) to find out whether or not the use of the stories is effective to improve the writing ability, (2) to find out which of the writing components that is mostly increased by the implementation of the use of stories.

This research was carried out on the second year students of MTs N Mangempang Barru. The writer employed a quasi-experimental design. This research assigned two groups namely experimental and control group. Each group consists of 24 students. The sample was using cluster random sampling. The experiment group of were taught by using stories while in other group taught by using mono text. The instrument of this research was writing descriptive text. The data obtained through the test were analyzed by using inferential analysis by some formulas.

Based on the result of research the mean score of post test of experimental group (73.42) was higher than the control group (69.50). The result of the t-test value (2.99) was higher than t-table value (2.021) . in other words, Ho was rejected and H1 was accepted..This means that the use of stories significantly improved the students' writing ability of the second year students of MTs N Mangempang Barru.
\end{abstract}

Keyword: writing, ability, stories, improving.

\section{Introduction}

In the Era of globalization, English is very important as a means of International communication. As an International language, English has many interrelationships with various aspect of life owned by human being. Therefore, English is one of the subjects taught in Indonesia. There are four skills that the students learn; they are: listening, speaking, reading, and writing. 
Since English as acknowledged as necessary to enable Indonesians to involve in global community. It is taught even from kindergarten. TEFL in compulsory in Junior High School according to the school based curriculum. In this curriculum, the students must be able to understand and create various kinds of short function and monolog text in the form descriptive, procedure, recount, narrative, and report. (Standard Isi dan Standar Kompetensi, 2006:212). Therefore, this curriculum is a genre based approach.

Based on KTSP (Education Curriculum in Indonesia) there are five genres of the text that must be taught to students in Junior high School. According to Harmer (2007:327) genre represents the norms of different kinds of writing. They write within a certain genre to consider number of different factors. They need to have knowledge of the topic, the convention style of the genre, and the content in which their writing will be read.

Writing skills are complex and sometimes difficult to teach, requiring mastery not only of grammatical and rhetorical devices but also of conceptual elements. Writing is a complex process that allows writer to explore taught, ideas, and makes them visible and go through available for reflection, when it thought is written down, ideas can be examined, reconsidered, added, rearranged and changed. (Gaith, 2002).

One of the techniques that can be used in teaching writing is stories technique. This technique trains the students to produce a good paragraph based on the text given. It concerns with how to write a correct sentence in good essay. As we know that stories guide us taught our whole life from the moment we were born and it does not change when we become teenagers or adult. When we are children, our parents tell us or read us stories and fairy tales, and when we are older we can hear it in radio or watch in TV. As pupil we have to create our own stories in writing. The writer believed that stories are important not only in our mother tongue but also in learning English in the classroom.

The writer observed that the second year students of MTs N Mangempang Barru still had low in writing competence. Therefore she wants to improve the students writing competence in learning writing using stories technique. The purpose of teaching writing is the students are expected to convey the accurately, fluently, and appropriately messages in short monologues/essays in daily life context and get access to popular sciences (standard of competence). Courses objectives students will be able to write a text well and correct. The stories is one of the technique will interest the students to learn more enjoyable and pleasant in the classroom.

Stories are very important for our psychical health. We learn our mother tongue through stories. So, it is natural to learn foreign language through them as well. Teachers should try to teach their students about language, life and culture through stories. So the writer find out the problem statement Is the use of stories effective to:improve the writing ability of the second year Students of MTs N Mangempang Barru? Therefore its aimed is whether or not the useof stoires is effective to improve the students writing ability.

\section{Discussion}

There are several empirical studies carried out on the effect the use of the stories in improving the writing ability to the second year students of MTs N Mangempang Barru.

Writing is one of the four components skills that it is important in English. There are some studies have been exposed and discussed by previous researches to identification of the students' motivation in learning English to make their teaching and learning process more effective in teaching writing, some of writers finding are cited concisely below.

Jamaluddin (2008) concluded that the second year students of SMP Negeri 3 
Mallusetasi had got significant development in writing ability through short story that is from poor to the pair classification. The research shows that there was a significant difference of the students writing ability before and after teaching writing through short story (t-test value = 24.350 is higher than t-table $=2.042$ ). It means that the use of short story is effective in developing the writing skill of the second year students of SMP Negeri 3 Mallusetasi especially in class $\mathrm{VIII}_{2}$.

Urbancova (2006) concluded that Using of stories in learning a language is an important teaching technique. Stories guide a human for his or her whole life and use them when the human learn his or her mother tongue. Consequently it is natural learn a foreign language with the help of stories.

According Psychologists believe that children need stories, legends and fairy tales when they grow up. They are a part of children's intellectual life. They provoke their fantasy and give them answers to important questions of a child's life. They are meaningful and effective item of their socialization. Myths and legends give material of which children make their concept of origin and purpose of the world and of ideals, which they may follow.

Based on the previous finding above, the writer concludes that the teaching and learning process can run well if the teacher using technique or method. Technique is a away used the teacher to teach the students in order to they get motivation to study, so that she used stories in this research to the writing ability.

Writing is meant to fill the gap that exist between the ability to press the ideas, feeling, opinion, in Indonesia, and the ability to express the things in English written form. There are some definitions of writing which stated by some experts:

Writing is continuing process of discovering how to find the most effective language for communicating one's thoughts and feelings. It can be challenging whether writing one's native language or in a second language.

Harmer (2005) states that writing is progress activity. It means that when you first write something down you have already been thinking about what are you going to say and how you are going to say it. Then after you have finished writing, you read over you have written and make change and correction.

The form of writing serves to attract the reader's attention and to include the type of writing to do the general plan of the written material. Correct spelling is the mark of a careful writer is correct capitalization, punctuation, and syllabication. Accurate capitalization and punctuation serve, futher, as signals to the reader to help correctly interpret meaning. The person who writes has to give attention to mechanics in writing.

Stories are a powerful means of language teaching. A skillful teacher can use stories to develop more efficient listening, more fluent speaking and write easily and competently. (Garvi in Marianne:144)

Story creates the deeper understanding about human nature experience when we hear or see what has happened to another human being. Whether it is an incident in the life of someone the true experience of someone in the news, the adventure of a fictional character, or heroic life of a compelling historical figure, we are fascinated by the progression of events that human being encounters, and this progression of events called plot.

A good story features a main character, or protagonist, who confronts a strong moral choice. This true in comedy as well as drama, and the best stories feature a protagonist who struggles with identifiable human flaws. The moral choice can be very simple or complex, but it must test inner moral strength of the main character against his human flaws.

Stories also develop the different type of "intelligences" that contribute to 
language learning, including emotional intelligence. Besides stories "develop children's learning strategies such as listening for general meaning, predicting, guessing meaning, hypothesizing. Stories can develop all of kinds of skill.

Stories are very important for children in learning their mother tongue, and they are important in learning any foreign language as well. That is why it is good to start using stories in teaching English as soon as possible. Primary school children enjoy listening to stories over and over again. This frequent repetition allows certain language items to be acquired while others are being overtly reinforced. Many stories contain natural repetition of key vocabulary and structures. This helps children to remember every detail, so they can gradually learn to anticipate what is about to happen next in the story. Repetition also encourages participation in the narrative. (Ellis and Brewster. 2002:2)

When children listen to stories in class they share social experience. It "provokes a share response of laughter, sadness, excitement and anticipates which is not only enjoyable but can help to build up the child's confidence and encourage social and emotional development". (Ellis and Brewster, 2002:1). "Stories are a useful tool in linking fantasy and the imagination with the child's real word. They provide a way of enabling children to make sense of their every life and forget link between home and school". (Ellis and Brewser, 2002:1)

Stories address universal themes which go beyond the useful level of basic dialogues and daily activities. "They allow children to play with ideas and feelings and to think about issues which are important and relevant to them". (Ellis and Brewster, 2002:2) They also provide "ideal opportunities for resenting cultural information and encouraging cross-cultural comparison". (Ellis and Brewster, 2002:2).

For teachers stories allow "to use a acquisition-based methodology by providing optimal input", (Ellis and
Brewster, 2002:2) It is great to use real story books because they "add variety and provide a spring board for creating complete units of work that constitute minisyllabuses and involve pupils, personally, creatively, and actively in an all-around whole curriculum approach. They there by provide a novel alternative to the course book". (Ellis and Brewter, 2002:2)

Based on definition above, the writer tries to implements in MTs N Mangempang to teach the students about stories in improving the writing ability in the classroom.

McKay and Dudley state that there are many different types of stories. The most important consideration when choosing a tale to tell is whether you like it enough to tell it with enthusiasm. Stories should communicate to you a need to be told. Some of the different categories of stories available to storytellers are: Fable, fairytale, folktale, Legend, Myth, Parable, Personal story, Religious story , Tall Tale, and Traditional.

Teaching stories is important to know, because it is an incident in the true life or adventure of someone in the past event. So the writer used stories to the students in order to they can write essay effectively based on the components of writing.

Based on some research findings and some pertinent ideas, the writer concludes that writing is an important aspect in learning English. The more writing skill of the students, the easier they do writing skill. Therefore, the writing process should more interesting and motivated for them. So, the students are interested to write some short composition based on the material given in every writing lesson.

In this case, the writer focuses on the components of writing. They are the content/supporting idea, sentence structure, vocabulary, and mechanic (spelling and punctuation mark). The success in learning writing is the students should be able to write and understand what they have 
written. The writer concludes that the technique in teaching is very important thing in order to the students can write writing well especially in using stories.

Based on the previous discussion related literature and the problem statement above, the writer tried to put forward by hypothesis follow:

Using stories technique can improve the students' writing ability.

\section{Method}

Research is an art and science in searching the answers of the problems (Yoseph and Yoseph, 1979 in Syamsuddin, 2011).

Method of the research is methodology refers to a design where the writers select the data collection and analyzed procedure to investigate a specific research problem.

Based on the aim of study, the writer used the experimental research. Experimental research approach is quantitative approach design to ferret out cause and effect relationship. According to Arikunto (2010) that experimental research is the way to look for the causality between two factors which intend to be generated by writer which eliminates other factors that disturbs. Experimental research is always done to see the effect of the treatment.

In this research, the writer applied a quasi-experimental study with nonequivalent control group design, this design almost the same with Pre-test Post-test control group design but the experiment and control did not choose randomly. The population of this research is students of MTs N Mangempang, and sample is VIII,3, tahun academic 2013/2014

The instrument of the research is writing skill test. The writer used instrument, namely writing skill test. The researccher gave the students four themes then they chose one then asked them to write a short essay with their own word at least 75 words in paragraph.

The writing skill applied in Pre-test and Post-test. The students in both groups were tested by the writer. The first test was Pre-test for both groups and it was intended to find out the students' prior knowledge and the initial skill before presenting the material is Post-test. The Post-test has given to both groups and designed to know how extent their achievement that they got after presenting the material. The Post-test has given after three times treatment. Both of them used in the same test in Pre-test. The writer gave the students some themes and they write an essay with their own words based on the components of writing. The allocation time was 40 minutes for each group and test form in Post-test is similar with in Pre-test. This aim to measure the students' knowledge based on the materials that were given.

The procedure of collecting data was divided into two steps, namely Pre-test and Post-test. The data from Pre-test were taken before treatment, while the data from Post-test were taken after the students join the treatment for three times.

To analyze the data, the writer collected through the test. She used descriptive and inferential statistic to find out the students' ability in a group writing essay. It viewed from five components; they are contents, organization, vocabulary, language use and mechanic. To measure the skill of each components of a good writing, she refers to ESL composition profile of Jacobs at all (2002).

If $\mathrm{t}$-table value is higher than t-test value, Ho (Null Hypothesis) is accepted and $\mathrm{H}_{1}$ (Alternative Hypothesis) is rejected. Based on the application of $\mathrm{t}$ - formula above that $\mathrm{t}$ - table value is higher than $\mathrm{t}$ test value. It means that null hypothesis (Ho) is accepted and the alternative hypothesis $\left(\mathrm{H}_{1}\right)$ is rejected. So, the students who were in the experimental group were better than the students who were be in the control group.

b. If t-test value is higher than t-table value, Ho (Null hypothesis) is rejected and $\mathrm{H}_{1}$ (Alternative hypothesis) is accepted. It means that there is significant different 
between the writing of the students who were taught using stories technique.

\section{Finding}

The result of the students' Pre-test score for both groups in writing skill test shows that in Pre-test of experimental group, the most of students are classified in poor category. There are 7 students $(29.17 \%)$ are classified fair and 17 students $70.83 \%$ ) classified poor. There are no students classified good, very good and very poor.

Meanwhile, the result of Pre-test of control group shows that most of the students are classified in poor category. There are 9 students $(44.44 \%)$ are classified in fair category, 15 students (55.56) are classified poor. There are no students are classified good, very good and very poor.

The data in Pre-test indicates that most of students are difficult to generate their ideas and construct an essay, in other words, the most of students are difficult to arrange sentences into a good essay based on the writing categories.

The result of the students' Post-test for both groups on writing skill test is in Post-test of experiment groups, most of students are classified in good category. There are 20 students $(83.33 \%)$ are classified good category, 4 students are classified fair category, and there is no students are classified very good, poor and very poor.

Meanwhile, the result of Post-test of control group shows that most of the students are classified in fair category. There are 8 students $(33.33 \%)$ are classified good category, 16 students (66.67) are classified fair. There are no students classified very good, poor, and very poor.

The data of Post-test indicates that after giving treatment through stories to the students is greater than the percentage in Pre-test. So using stories is effetive if used to improve the students' ability in writing skill.
The test result of the students' means score and standard deviation of experimental and control group that the mean score of the students' Pre-test of experimental group is 54.13 and standard deviation is 4.10 , it is categories as poor classification. Meanwhile, the mean score of the students' Pre-test of control group is 52.96 and standard deviation is 5.75 , it is also categories as poor classification. It means that the students' mean score between experiment and control group are almost same. In this case, the experimental and control group have the same knowledge before treatment.

The test result of students' mean score and standard deviation of students' Post-test of experimental and control group presented that the mean score gained by the students is different. The data shows that the mean score of the students' Post-test of experimental group is 73.42 and standard deviation is 4.18., which category good classification. It means that the mean score increase about 19.29 point. While the mean score of control group is 69.50 and standard deviation is 4.70 , which is categorized as fair classification.

In other words, the result of Posttest of experiment group is better than the result of Post-test of control group. Furthermore, the score of students' writing skill in Post-test of two groups get improvement. The data indicates that after getting treatment through stories technique, the students' score of experimental group is higher that the students' score of control group.

Based on the description above, the students of MTs Negeri Mangempang Barru are effective in learning writing using stories techniques.

To know the significant different between the result of students' mean score of experiment group and control group on Pre-test, the writer used t-test (test of significant). Before treatment, the writer found that the t-Test value was 0.82 probably significance was 2.021 or the 
probably was higher than 0.05 as the level of significance for two tailed test, and the degree of freedom (df) $=46$, so $(0.82<$ 2.021). It means that there no different statistically between the Pre-test of two groups.

The mean score of two groups as the result of Post-test then analyzed by using tTest formula to see whether there is significant different of students' writing skill between experiment and control group after giving treatment.

After calculating the students' score of the two groups before treatment, the writer found that the t-test value 2.99 by probability significance was 2.021 or the probability was higher than 0.05 as the level of significance for two tailed test, and the degrees of freedom (df) $=46$, so $(2.99$ $>$ 2.021). This means that there was significance different between students was taught using stories teaching technique and the students taught through conventional technique. In other words, the alternative hypothesis $\left(\mathrm{H}_{\mathrm{a}}\right)$ was accepted and the null hypothesis $\left(\mathrm{H}_{0}\right)$ was rejected.

The writer conducted two main objectives in this experimental research study. The first was to find out whether or not the use of stories is effective to improve the writing ability of the second year students of MT N Mangempang Barru. The second is to find out which writing component is mostly increased using the stories technique.

The implementation of this research is the writer gave the students pretest to experimental and control group then she analyzed but the students' score still low. After that she gave treatment until three times and the last step she gave post-test.

To analyzed the data the writer used descriptive inferential to analyze them using some formulas. The data acquired from the final result writing in Pre-test and post-test in both experimental and control groups were in poor category. While in the post-test the experimental group increased to a good category but the control group was in fair category. So, there was significantly difference between the students' pre-test and post-test scores. It meant that the students' achievement in writing is greater than in control group.

The mean score of the student's pretest for the experimental group was 54.13 and control group was 52.96 and the mean scores of post-test for experimental group was 73.42 and control groups was 69.50. It means that the student's mean scores of pre-test and post-test was statically different cause of most of the students interested in the application of stories technique in improving the students' writing ability.

It appears that the mean score of the Post-test obtained by the students in both group are different, (see table 9) where ttest value is greater than $\mathrm{t}$ - table value (see table 10). The t- test value of pre-test was 0.82 and $t$-table value was 2.021 and $t$ - test value of post-test was 2.99 and t-table was 2.02. It means that the statistical hypothesis H1 was acceptable and Ho was rejected. The writer found that the students' writing score significantly increased from pre-test to post-test. So, the achievement of the students who were treated stories technique had a significant different between the students who were taught using mono text. Therefore, entirely, the result of this research study proved that the implementation of story technique improved significantly to the students' writing ability in the second year students of MTs N Mangempang Barru because it can made progress on students' writing skill.

Moreover it was caused some steps or sequences in writing activity. The sequences are, the students were given a chance chose the topic then, they wrote some possibilities of ideas concerning. In this case, they expressed their ideas into word phrase, or piece of information form. After that, they classified their ideas. At the same time, they leave out ideas there ware not suitable with the topic. At last, they rearranged their ideas into a good order. There fore, they have a good content and organization in writing essay. 


\section{CONCLUSION AND SUGGESTION}

\section{Conclusion}

In relation to the research finding and discussion in the previous chapter, this research shows that the use of stories improved signification because the students can arrange the sentences into a good essay. It shows that mean score of experimental group in post-test and control group were significantly different. The mean score of post-test in experimental group is higher than the control group $(73.42>69.50)$.So, the students' achievement in writing essay getting improvement. As a result, it means that there is significant between the students who were taught the use of stories in teaching writing and whom were not taught through it. Therefore, this research proved that the use of stories in teaching writing to the second year students of Madrasah Tsanawiyah Negeri Mangempang Barru has a significant influence in improving the students' skill in writing an essay. In shortly, the use of stories technique is effective to teach the students in the classroom.

\section{Suggestion}

In relation to the English subject discussed in this research is to improve the students' ability in writing essay at school, the writer deals with some suggestions as follows:

1. The English teacher should be using stories in teaching writing so the students can improve their ability in writing essay, because this technique is good to implement in the classroom. In this research the students' score is higher after treatment.

2. The English teacher should give enough opportunity to the students to improve their achievement to learn by practicing their ability to write essay using stories technique.

\section{References}

Alimuddin, Andriani, 2008. Improving the Writing Ability of the First Year
Students of SMP Negeri 3 Suppa By

Using Sequence Pictures.

Brown, H. Douglas. (2001). Teaching by Principles; An interactive Approach to Language Pedagogy. $2^{\text {nd }}$ ed. New York. Longman.

Byrne. 1997. Teaching Writing Skill. 'new Edition'. New York. Longman.

Celce, Marianne. 2002."Teaching English as a Second or Foreign Language" united kingdom.

Chitravelu. 1997. ELT. Techniqueology, Principle and Practice. Selangor Darul Ehsan Malaysia.

Cornbleet and Carter. 2001. The language of speech and Writing. London New York. Routhledge.

Depdiknas. 2003. Langkah-Langkah Penyusunan Soal, Pedoman Penskoran, Cara Penskoran, dan Cara Perhitungan Nilai Akhir SMU/SMK. Jakarta.

Ellis, Gail and Brewster, Jean. 2002.Tell it Again!, Penguin , ISBN: 0582-44777-1

Friedman, tew Howa. 2 minute storiy helps you lead, harrard Bussiness, review August 4, 2009.

FÜRST, Maria: Psychologie, Votobia, 1997,ISBN 80-7198-199-0

Gargiulo. Terrence L. 2005. The strategy use of stories in organization Communication and learning. NE Sharpe.ISBN 0-7656-1413-8.

Gay, L.R. 1981. Educational Research Competencies for Analysis and Application. Second Edition Columbus, Ohio. Charles E. Meril Publishing. 
Hadijah. 2009. Teaching Writing by Using Paraphrasing Reading passage strategy to the second year students of SMA Wahyu Makassar

Hajar, sitti at all. 2013. "Pedoman Penulisan Thesis".Universitas parepare.

Harmer,J. 1997. Introduction to Academic Writing. Longman

Harmer, J. 2005. The Practice of English Language teaching. Longman, ISBN 0-582-40385-5.

Harmer, J. 2007. How to Teach English. Pearson Longman.

Haryadi and Zamsani. 1996. Peningkatan Keterampilan Berbahasa Indonesia.

Hendrawati, 2008. Teaching Writing to the Students of SMP PGRI 1 Parepare By Using Picture Series.

http:'//www.teachinglistorg,uk/blogs/verdia $\mathrm{n} /$ classroom action-research-aproffesionan-development process.

http://nuralfilaela.blogspot.com/2013/04/the -effectiveness-of-using-mindmapping.html.

http://www.skwirk.com/p-c_s-6_u-124_t-

341_c-1183/personal-response

/nsw/personal-response/texttypes/understanding-different-texts

(based on: http://psychologie.doktork+a.cz/pohadky-nasi-dusi-vyvojove/ ) http:/

technologysource.org/extra/113/Defin ition $/ 3$

Jabu, Baso. 2008. Language Testing. Makassar Badan Penerbit UNM.

Jacobs. M.G. Daud Hall,C Hidalgo Aracile. (1995). Getting Started: Material Writer on Material Writing: Singafore Regional Language Centre.

Jamaluddin. Sayyid, 2008. Developing

Writing Ability of the Second Year Students of SMP Negeri 3 Mallusetasi through Short Story.

Jung. 1990. An Introduction to Action Research. Volume 7 issue, (1991 pages

119-136), http/www.emtch.net//actionresearch.h tm

Lewin Kurt. 1996. Classroom Action

Research: a Proffessional

Developmnet process. On 20

february, 2009. Page 12

.MS. Sri Wahyuni. 2004. Improving The Writing Ability Of The Second Year Students Of Madrasah Aliayh Negeri 1 Makassar Through Free Composition

Maming, Hadijah. 2012. The Effectiveness of Brainstorming technique in Impropving the Writing Skill of the English Departement students at Muhammadiyah Pare-Pare.

Mckay. Hand Dudly B. 1996 Types of stories from story telling, Sidney Australia.

Mustafa Fatimah, Syafrianti. 2008. Skripsi "Improving The Student Ability To Depelop Paragraphs of The Second Year of SMA Negeri 1 Pangkep through Tables".

Nation. 2008. Teaching ESL/EFL Reading and Writing. Routledge in the Tylor and French.

Nunan. 1990. Action Research in the Language Classroom, Ind. Numan (eds) second teacher education (pp. 62-81) Cambrige University Press.

Nunan, David. 1991. Language Teaching Techniqueology. Sydney: Macquire University

Nursiah. 2012. The application of the integrating the teaching of sentence structure and the teaching of writing 
in improving the students' ability in writing a short narrative composition at SMA Negeri 1 Barru.

Rahmawati, 2008. The Use of Three Stages of Writing Process to Contribute the Writing Skill of the First Year Students of Tata Busana's Department Of Smk Negeri 3 Parepare

Randu, Pranata Andi, 2008. Improving The Writing Ability Of The Eight Grade Students Of Smp Muhammadiyah Parepare By Using Scrambled Words.

Richard, C. Jack, 1996. Teacher as Course Developers. Australia: Cambrige University Press.

Sommer and Trimers. 1983. Writing with a purpose. Boston: Houghton Miffin Company

Simanjuntak, Hepinus. 1994. Bahsa Inggris system 52 M. Bekasi: Visipro

Sugiyono. 2006. Statistik Untuk Penelitian. Bandung: Alfabeta

Sugiyono. 2003. Metode Penelitian Adminstrasi. Bandung : Alfabeta

Sulaeman. 2009. Using guided question to Improve the Students' ability to write Narrative paragraphs.

Syam, Haeruddin. 2003. The ability to write on English Composition through parallel writing Technique.
Syamsuddin and Damaianti, V, S. 2011. Metode Penelitian Pendidikan Bahasa. Bandung: PT. Remaja Rosdakarya.

Tompkins, Gail E and Kenneth Hoskisson, 1991. Language arts, content and teaching strategies, New York Macmillan Publishing Company

Tabachnick and Zeicher. 1999. Researching school experience. 1999. Pages 134. http://tstc.wikidot.com/definition-ofaction-research.

Urbancová, Žaneta. Using Stories in Teaching English : Bakalářská práce. Brno: Masarykova univerzita, Fakulta pedagogická, Katedra anglického jazyka a literatury, 2006.

Weigle, cushing Sara, 2002. Assesting Writing, New York. Cambrige Univercity Press.

William. Mixed Text Types Understanding different text, text types, English Year 6.

Wilga, Rivers. 1987. Interactive Language Teaching. USA: Cambridge University Press.

Wrigh, Andrew. 1997. Creating Stories with Children. ISBN, 019-437204-9 